\title{
ANALISIS HUBUNGAN ENJOYMENT, ENTERTAINMENT, EDUCATION, FLOW DAN DESIGN BACKGROUND DALAM VIRTUAL TOURISM SELAMA COVID-19
}

\author{
Nur Amalyna Yusrin ${ }^{1}$ \\ Pradita University, Indonesia \\ nur.amalyna@pradita.ac.id \\ Natasya Sugianto ${ }^{2}$ \\ Pradita University, Indonesia \\ natasya.sugianto@student.pradita.ac.id \\ Diterima 8 Maret 2021 \\ Disetujui 3 Juni 2021
}

\begin{abstract}
COVID-19 has a significant impact for Indonesian tourism industry and MSMEs (Micro, Small, Medium, Entreprises) where are strong leaning on direct interaction. This condition causes has a significant impact on the decline of national tourism economy. It impacts to a contraction of $88.82 \%$ in 2020 which increases the risk of loss by IDR 54.6 trillion if it occurs during the year. It is as a result government's policy to keep the distance to break the COVID-19 spread however, tourism well known as an industry where cannot be separated by human touch and visitors direct experience. In this digital development era, virtual tourism becomes the alternative solution to reduce contraction rate implemented by tourism entrepreneur and the Indonesian Ministry of Tourism and Creative Economy. When talking about technology, we will discuss how it is executed in the present and the development of its implementation for the next 10 years. Existing research focuses on the marketing elements of virtual tourism, therefore, it is important to analyse which elements in the virtual tourism experience are able to attract the attention of tourists for continuance using virtual tourism. Researcher implement quantitative methods by distributing questionnaires to 308 respondents to millennial labor force in urban cities. Researchers used TAM (Theory of Acceptance Model) to see the effect of enjoyment, entertainment, education as Perceived Ease of Use (PEOU) and Flow and Design Background as Perceived Usefuless (PU). The results of this study indicates Education, Flow and Design Background elements have direct positive effect on increasing tourist attention using Virtual Tourism. This research is expected to be able to contribute to the development of virtual tourism technology and how it is implemented in Marketing 5.0
\end{abstract}

Keywords: Virtual Touris; Continuance Purchase Intention; Percevived Eased of Use; Perceived of Usefulness

\section{PENDAHULUAN}

\subsection{Latar Belakang}

COVID-19 adalah virus yang menyerang sistem pernapasan dan menyebabkan penyakit seperti batuk dan lebih parahnya memberikan sindrom seperti pernapasan timur tengah (MERS-CoV) dan sindrom pernapasan akut (SARS-CoV) (World Health Organisation, 2020). COVID-19 memberikan dampak yang signifikan terhadap berbagai sektor penting seperti perekonomian global, politik, sosial dan budaya (Hanoatabun, 2020). Dilihat dari pertumbuhan ekonomi Indonesia triwulan II 2020, pertumbuhan produk 
domestik bruto (PDB) Y-on-Y sebesar -5.32\%, dengan kontraksi paling dalam dari sektor transportasi dan pergudangan ( $Q$ to $Q$ ). Data di atas mengatakan bahwa, daya beli dan konsumsi masyarakat menurun karena berkurangnya jumlah penghasilan masyarakat.

Kebijakan pemerintah untuk mengurangi jumlah penyebaran COVID-19 seperti social distancing, pembatasan jumlah mobilitas dan wisata, community lockdowns, kampanye "di rumah saja", self atau mandatory quarantine, serta curbs on crowdfunding berimbas buruk kepada pariwisata global, tourism dan leisure karena berkurangnya jumlah wisatawan lokal dan mancanegara (Sigala, 2020). Menurut Badan Pusat Statistik (2020), secara kumulatif (Januari-Juni 2020), jumlah kunjungan wisman ke Indonesia mencapai 3,09 juta kunjungan atau turun 59,96 persen dibandingkan dengan jumlah kunjungan wisman pada periode yang sama tahun 2019 yang berjumlah 7,72 juta kunjungan (Badan Pusat Statistik, 2020b). Menjadi industri yang sangat rentan terhadap berbagai risiko lingkungan, politik, sosial, budaya dan ekonomi (Japutra \& Situmorang, 2021), industri pariwisata menjadi sulit untuk bangkit karena COVID-19 berdampak perubahannya secara struktural dan transformasional (multiplier effect) (Novelli et al., 2018; Mufti, 2020). Sebab, sektor pariwisata ditopang oleh beragam sub-sektor seperti UMKM, transportasi dan akomodasi (CNN Indonesia, 2020).

Fenomena lain yang diciptakan oleh COVID-19 adalah berubahnya pola konsumsi masyarakat Indonesia (Silalahi, 2021). Demi memutus rantai penyebaran COVID-19, masyarakat beralih menggunakan internet untuk memenuhi kebutuhan hidupnya dan menjadi digital savvy. Perubahan pola konsumsi ini ditunjukkan dengan peningkatan penggunaan internet serta meningkatnya tingkat unduh aplikasi mobile di Indonesia selama pandemi COVID-19 (Kemp, 2021). Masyarakat menggunakannya untuk memenuhi kebutuhan primer, yaitu belanja kebutuhan pokok harian melalui aplikasi $e$ commerce. Selain itu, penggunaan aplikasi mobile entertainment seperti YouTube, Netflix, Spotify dan jumlah Premium Users baru untuk aplikasi tersebut juga meningkat selama pandemi COVID-19. Ini terjadi karena peningkatan belanja iklan televisi dan media digital. Pola konsumsi tersebut menyebabkan perubahan pola belanja masyarakat di Indonesia (Media Partners Asia (MPA), 2021).

Selain aplikasi mobile entertainment, terdapat trend baru yang terjadi di Indonesia dalam industri hiburan yaitu Virtual Concert dan Virtual Tourism (Sari et al., 2020). Virtual Reality (VR) merupakan dasar teknologi dimana Virtual Concert dan Virtual Tourism dapat dilaksanakan. VR dapat digunakan dalam entertainment, design, simulasi latihan serta memiliki beberapa kegunaan dalam sektor pariwisata. Semakin berkembangnya VR, tidak diragukan lagi memberikan implikasi terhadap industri pariwisata sehingga para pengusaha dapat menghadapi dampak COVID-19 serta mengambil keuntungan dalam hadirnya teknologi VR. Usaha perbaikan di bidang digital, didukung oleh Kementrian Pariwisata dan Ekonomi Kreatif RI (Kemenparekraf) dimana menginisiasi program akselerasi digital untuk menghidupkan kembali musik tradisi (Kemenparekraf, 2020; Wratsangka, 2020).

Dilihat dari sisi theoretical gap, implementasi teknologi dalam membantu bisnis sudah banyak dilakukan akan tetapi jarang sekali ada penelitian membahas Virtual Tourism terutama di Indonesia (Lou et al., 2020). Ini menyatakan, bahwa perkembangan teori dan keilmuan mengenai Virtual Tourism perlu dikembangkan lebih lanjut. Dalam segi empirical gap, penelitian yang ada hanya terfokus pada bagaimana VR berpengaruh kepada sisi Marketing (Beck et al., 2019). Dimana, fokus akhir yang ingin ditemukan oleh penelitian sebelumnya tentang bagaimana peran Virtual Tourism dalam segi branding tujuan wisata. 
Maka dari itu penelitian ini ingin bergerak dari hal paling dasar yakni bagaimana tanggapan konsumen terhadap implementasi Virtual Tourism di lapangan. Dari $>40$ faktor yang dijabarkan dalam penelitian sebelumnya dalam jurnal Beck, Rainoladi dan Eggar (2019), fokus penelitian ini akan berada di antara faktor-faktor yang mempengaruhi atensi konsumen menggunakan Virtual Tourism sebagai alternatif pengganti wisata yang berbasis virtual saja. Memang Virtual Tourism menjadi sangat relevan di tengah pademi COVID-19, sebab sektor pariwisata yang terkena imbas lock down harus mencari strategi baru supaya sektor ini masih tetap bisa menghasilkan income.

Penelitian ini bertujuan untuk memanfaatkan Digital Technology for Industrial Revolution 4.0 terhadap salah satu industri yang paling terkena terdampak COVID-19 yaitu pariwisata dimana mampu mendorong sustainable tourism melalui penelitian terhadap Virtual Tourism. Masalah yang terjadi di tengah pandemi COVID-19 ini adalah tantangan dalam bagaimana implementasi Virtual Tourism kepada masyarakat luas. Penelitian ini menggunakan model TAM (Theoretical Acceptance Model) sebagai dasar untuk menjawab tantangan dalam implementasi Virtual Tourism bagi masyarakat luas (Lee, 2010). Perceived Ease-of-Use (PEOU) menjelaskan bagaimana teknologi memudahkan pengguna dalam penggunaan inovasi atau teknologi baru sedangkan, Perceived-Usefulness (PU) menjelaskan bagaimana inovasi atau teknologi terbarukan mempermudah proses pengalaman penggunaan (Ekasaputri \& Aruan, 2018). Karena Virtual Tourism merupakan teknologi yang sedang dimutakhirkan, TAM menjadi metodologi yang ideal untuk menguji pengaruh masing-masing elemen terhadap atensi wisatawan. Secara garis besar masalah yang ingin diuji dalam penelitian ini adalah:

1. Apakah faktor Enjoyment mempengaruhi atensi wisatawan menggunakan Virtual Tourism?

2. Apakah faktor Entertainment mempengaruhi atensi wisatawan menggunakan Virtual Tourism?

3. Apakah faktor Education mempengaruhi atensi wisatawan menggunakan Virtual Tourism?

4. Apakah faktor Flow mempengaruhi atensi wisatawan menggunakan Virtual Tourism?

5. Apakah faktor Design Background mempengaruhi atensi wisatawan menggunakan Virtual Tourism?

Diharapkan hasil yang ditemukan dapat memberikan masukan dalam implementasi dan rancangan Virtual Tourism di Indonesia berdasarkan perspektif konsumen. Yang selanjutnya dapat menjadi bahan mengembangkan potensi bisnis Virtual Tourism di Indonesia.

\subsection{Tinjauan Pustaka}

\subsubsection{Digital Teknologi 4.0 untuk Pariwisata Indonesia}

Information and Communications Technology (ICT) telah menjadi bagian dari mayarakat karena memiliki peran penting pada kehidupan yang mampu menghubungkan manusia dengan manusia serta manusia dengan benda dalam berbagai macam aspek. Personal computer $(P C)$, smart electronic seperti smart watch dan smart homes, entertainment, transportation, social media dan online video merupakan beberapa contoh dari ICT (Xu et al., 2014).

Hal tersebut membuka jalan baru menuju Internet of Things (IoT) dimana seluruh produk dan aktivitas manusia tersambung dengan internet yang bertujuan untuk memudahkan kehidupan manusia. IoT diprediksi memudahkan operasi inteligen dalam berbagai bidang, salah satunya adalah media komunikasi serta servis (Coetzee \& Eksteen, 2011). IoT 
menghubungkan berbagai objek yang memiliki kode masing-masing, sehingga dapat berintegrasi satu sama lain untuk mengumpulkan, mencari, memproses serta bertukar informasi melalui aplikasi dan management system yang tersimpan dalam pusat data atau jaringan clouds (Abdul-Qawy et al., 2015).

Javaid, et al. (2020) menyatakan bahwa salah satu keuntungan yang didapatkan dari industri digital 4.0 adalah penyedia inovasi dan penyedia pengalaman secara digital yang dapat dimanfaatkan untuk industri pariwisata sebagai salah satu industri yang paling terkena dampak COVID-19. Hal ini selaras dengan rencana Kementrian Perindustrian yaitu Making Indonesia 4.0, dimana salah satunya adalah mengembangkan bisnis yang dimiliki oleh UMKM (Puspita, 2019; Badan Koordinasi Penanaman Modal, 2020). Dimana, UMKM merupakan penyokong dari tumbuhnya bisnis pariwisata di Indonesia

Di Indonesia, pertumbuhan industri digital 4.0 dalam bidang pariwisata sudah terjadi semenjak munculnya Online Travel Agent seperti Traveloka, Tiket.com, PegiPegi, AirBnB yang telah memanfaatkan penggunaan Big Data yang merupakan bagian dari IoT untuk proses bisnis mereka (Surwani et al., 2020). Penelitian tersebut menunjukkan bahwa jika industri pariwisata ingin dapat bersaing maka haruslah beradaptasi dengan perubahan pola perilaku konsumen yang berorientasi pada perubahan pasar, misalkan bertambahnya profil wisatawan diakbitkan dari pertumbuhan industri digital 4.0. Salah satu cara yang dapat membantu industri adalah berkolaborasi (sharing economy) dengan berbagai macam penyelia digital dan UMKM lainnya serta tetap mempertahankan inisiatif dan kreatifitas (Surwani et al, 2020).

\subsubsection{Virtual Tourism}

Tourism 4.0 merupakan paradigma baru yang menggunakan trend terbaru dalam melakukan proses big data yang didapatkan dari banyaknya sumber data wisatawan untuk membentuk sebuah pengalaman pariwisata pribadi (BCC, 2018; Korže, 2019). Fokus dari Tourism 4.0 adalah komunitas lokal, seperti UMKM dan bukan hanya turis. Salah satu bentuk Tourism 4.0 adalah Virtual Tourism yang memanfaatkan teknologi Virtual Reality (VR) ke dalam industri pariwisata. Wisatawan melakukan Virtual Tourism dalam fiksi atau aktual lokasi wisata, dimana wisatawan mampu merasakan pengalaman menikmati pemandangan 360 derajat video berlibur menggunakan VR (ibid.). Salah satu Virtual Tourism yang pernah diimplementasikan adalah pada Virtual Reality Theme Park, Guizou, China (BCC, 2018). Augmented Reality (AR) memudahkan wisawatan untuk mendapatkan pengalaman wisata yang mulus (seamless), interaktif dan sederhana (Korže, 2019). Teknologi AR hampir serupa dengan VR, namun AR tidak dapat menggantikan lingkungan actual di dunia. AR hanya menambahkan beberapa komponen digital dalam medianya (ibid.).

Virtual Tourism merupakan gabungan (hybrid model) antara teknologi VR dan AR yang mampu menghadirkan pengalaman mengunjungi objek wisata melalui media teknologi digital tanpa wisatawan harus menghadiri lokasi tersebut (Stainton, 2020). Virtual Tourism dapat memberikan dampak positif ke lingkungan alam objek wisata karena wisatawan tidak bersentuhan langsung dengan panorama, lebih murah, dan memberikan kesempatan untuk wisatawan melakukan apapun dalam dunia digital Virtual Tourism (ibid.) Konsekuensi dalam Virtual Tourism adalah tidak dapat dijangkau oleh semua wisatawan karena minimnya teknologi, tidak memberikan kenaikan langsung untuk daerah wisata kecuali yang telah bekerjasama dengan penyelia Virtual Tourism (ibid.).

\subsubsection{Enjoyment}

Enjoyment merupakan tingkatan kepuasan, kertertarikan seseorang dalam menikmati penggunaan media, dalam konteks penelitian ini yaitu Virtual Tourism (Huang Y.-C. , 2013). 
Enjoyment melibatkan unsur kebutuhan psikologis yaitu kompetensi (competence), autonomi (autonomy) dan hubungan (relatedness) (ibid). Dalam Virtual Tourism, elemen enjoyment mengindikasikan adanya perasaan "berada di sana", persepsi efektifitas dalam menggunakan teknologi serta keyakinan bahwa perjalanan Virtual Tourism akan berguna untuk perjalanan mereka ke lokasi tersebut (ibid.)

Enjoyment berguna untuk melihat apakah motivasi pengguna dalam menggunakan Virtual Tourism salah satunya agar mendapatkan kepuasan. Menurut Goh dan Yoon (2011), enjoyment berkontribusi terhadap keinginan pengguna dalam menggunakan fitur dunia virtual yang memiliki hubungan erat terhadap hedonic. Yang artinya, konsumen rela membayar sejumlah uang untuk mendapatkan kepuasan dalam menggunakan teknologi virtual world (Goh \& Yoon, 2011). Pernyataan tersebut diperkuat oleh Disztinger, Schlögl, dan Groth (2017), dimana faktor enjoyment merupakan elemen prediktor yang baik untuk memprediksi tourist's intention dalam berbelanja produk travel digital.

Tussyadiah, Dan, Jung, \& Dieck (2018) menginvestigasi pengaruh antara presence dan elemen enjoyment dalam Virtual Tourism. Diidentifikasi bahwa terdapat pengaruh signifikan untuk kedua elemen tersebut. Keberadaan diri ikut serta dalam pengalaman Virtual Tourism membawa faktor enjoyment (Tussyadiah et al., 2018). Bagaimana tourist's intention berinteraksi dengan media dapat diukur dengan enjoyment, terutama dengan media yang interaktif (Shafer et al., 2019). Enjoyment mengacu kepada kebahagiaan (fun) yang diterima wisatawan selama pelayanan diberikan (Gonza'lez-Rodrı'guez et al., 2020). Faktor keramahan dan pelayanan menjadi elemen lainnya yang mendukung enjoyment (ibid).

\subsubsection{Entertainment}

Entertainment dalam tourism adalah lokasi dimana pengunjung dapat merasakan kebahagiaan dan kesenangan dengan melakukan aktivitas yang menghibur, seperti konser, acara musik, festival, pertunjukan sulap, komedi, olahraga hingga taman bermain (Besciu, 2013). Dalam konteks Virtual Tourism, entertainment dikategorikan sebagai aktivitas yang melibatkan pengunjung dalam pengalaman perjalanan virtual mereka. Misalkan, pengunjung diajak untuk menebak ciri-ciri dari suatu tempat, atau peserta diajak untuk merasakan simulasi virtual menggunakan teknologi AR, sehingga mereka mampu membayangkan diri mereka berada di lokasi tersebut (Guttentag, 2010; Huang Y-C. et al., 2016).

Fantasi membantu konsumen dalam merasakan hiburan (entertainment). Fantasi disimulasi oleh virtual tour yang mereka ikuti, dengan objek gambar dan suara (Huang Y.C et al. 2013; Najafipour et al., 2014; Yuce et al., 2020). Bentuk hiburan yang ditawarkan, dapat berupa video 360 derajat yang menunjukkan lokasi tujuan wisata secara virtual (ibid.). Virtual Tourism mampu memberikan potensi membantu pariwisata. Di Indonesia, perusahaan teknologi raksasa Google melalui Google Arts and Culture, memungkinkan pengunjung melakukan wisata secara virtual (Maranti, 2020). Cara kerja Google Arts and Culture serupa dengan Google Maps Street View, dimana pengunjung dapat melihat-lihat objek wisata dipandu oleh pemandu wisata lokal (The Jakarta Post, 2020; Maranti, 2020). 


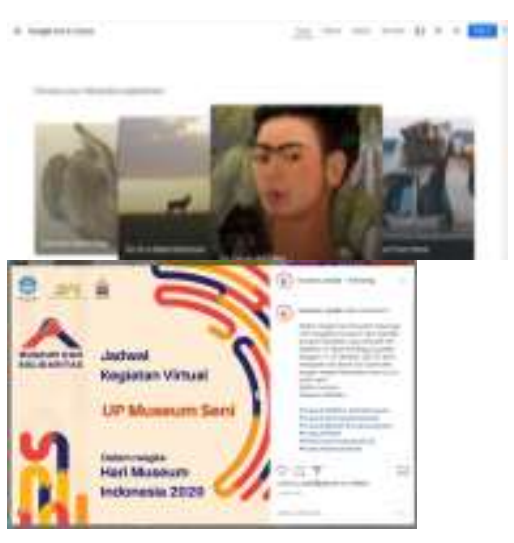

Gambar 1. Google Arts and Culture

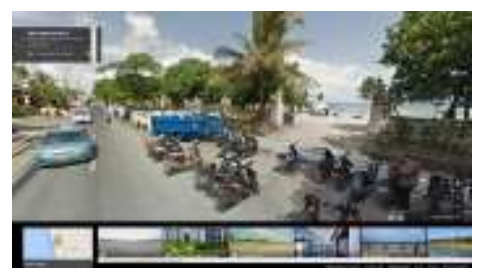

Gambar 2. Contoh Google Maps Virtual Tour Bali Gambar 3. Poster Virtual Tour Museum Seni

\subsubsection{Education}

Educational tourism atau dikenal dengan edu-tourism merupakan bagian dari pengalaman self-improvement dan self-actualisation (Šimková \& Holzner, 2014). Proses belajar menjadi lebih menyenangkan ketika digabungkan dengan jalan-jalan, karena jalanjalan merupakan bagian dari relaksasi. Terlebih, tidak atas batasan umur dalam berwisata. Sehingga self-improvement dan self-actualisation tercapai (Future Market Insights, 2020). Edu-tourism memiliki keuntungan dari "Education with travel" dibandingkan dengan mempelajari via teori (ibid.). Konsep wisata sambil belajar didukung dengan fasilitas dan teknologi yang memadai, terutama koneksi jaringan internet.

Singh dan Lee (2008) menggunakan menggunakan TAM (Technology Acceptance Model) dalam penelitiannya mengenai 3D Virtual Environments, bersandar pada faktor PU (Perceived of Usefulness) dan PEOU (Perceived Ease of Use) dalam proses. Disimpulkan bahwa edukasi mampu meningkatkan unsur usefulness dan playfulness. Disebabkan, semakin tingginya ekspektasi sebelum mengikuti Virtual Tourism, maka semakin tinggi intention to use mereka (Singh \& Lee, 2008). Namun, faktor eased of use terhadap audience's intention tidak signifikan. Disebabkan, audience yang merupakan savvy technology, merasa kemudahan bukanlah merupakan faktor penting (ibid.). Dalam bidang industri, edu-tourism dalam Virtual Tourism juga diminati oleh wisatawan yang memang sudah memiliki rencana untuk berkunjung ke negara tersebut. Sehingga mereka dapat merencanakan wisata mereka dengan baik (Huang et al., 2010; Najafipour et al., 2014; Tussyadiah et al., 2017; Pestek \& Sarvan, 2020). Namun, perbedaan standar fasilitas teknologi dan internet memungkinkan terjadinya noise selama pembelajaran (Deale, 2013). Sehingga, penangkapan yang diterima audience dapat bervariasi kedalamannya (ibid.).

\subsubsection{Flow}

Flow atau navigasi termasuk dalam seberapa nyamannya pengalaman pengguna dalam mengikuti pengalaman Virtual Tourism (Guttentag, 2010). Flow menggambarkan pengalaman untuk merasakan kendali, merangsang fokus dan rasa keingintahuan serta ketertarikan secara instrinsik dalam Virtual Tourism. Seberapa siapkah penyelia Virtual Tourism dalam menyajikan informasi dan menyusun jadwal kunjungan secara virtual sehingga tercipta kenyamanan dalam proses Virtual Tourism (Huang, Y-C, 2011).

Flow erat kaitannya dengan User Experience (UX). Jika unsur interaktif kurang memadai, misalkan kurangnya tautan (link) tambahan yang membantu pengunjung mendapatkan informasi lebih, pengapdopsian tujuan wisata dalam Virtual Tourism menjadi tidak maksimal (Osman et al., 2009). Maka dari itu, interaksi dua arah juga 
diharapkan dilakukan dalam pengenalan flow. Dalam Virtual Tourism, pengunjung ingin mengetahui aktivitas serta informasi apa yang akan mereka dapatkan dalam Virtual Tourism sebelum melanjutkan pengalaman. Kejelasan menu utama, kemudahan pencaharian, serta familiaritas menjadi elemen penting demi mendukung kejelasan flow (Adriyanto \& Triani, 2015). Berikut merupakan contoh pengenalan rute sebagai salah satu icon simbolis untuk menunjukkan flow serta menavigasikan pengunjung dalam Virtual Tourism.

Navigasi dalam Virtual Tourism mendorong emosi positif, flow dan keterikatan emosional yang menghasilkan efek positif terhadap atensi pengguna sehingga terciptanya keterikatan mendalam dalam pengalaman pengunjung (Jung et al., 2017). Pengaplikasian

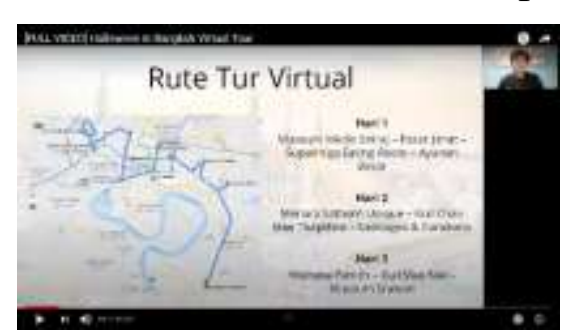

\subsubsection{Design Background}

Adytio, Niswar, \& Ilham (2017) menjelaskannya dalam pengertian multimedia dimana menggabungkan lima elemen yaitu teks, grafik, suara, video dan animasi yang saling bersinergi untuk mendukung website virtual tour. Design background erat kaitannya dengan unsur User Interface (UI). UI merupakan konsep yang menggambarkan estetika dari sebuah website yang menjadi komunikasi gerbang utama dari penyelia website kepada pengguna (Cao et al., 2015). Yuliana dan Lisdianto (2017) menguraikan bahwa perancangan design yang baik terutama untuk virtual tour panorama 360 perlu menambahkan fitur multimedia dan obyek animasi sehingga pengalaman yang didapatkan pengguna lebih maksimal. Hal menarik yang harus dikembangkan selain estetika adalah pengadopsian unsur budaya lokal tujuan wisata sehingga menjadi daya tarik pengunjung (Yuan et al., 2016). Virtual Tour menggunakan unsur permainan (games) interaktif dalam penyajian Virtual Tourism dengan menampilkan logo dan symbol yang mudah diikuti. Hal tersebut menjadi salah satu hal yang menarik karena pengunjung tidak merasa digurui dengan adanya penampilan logo yang jelas dan menarik.
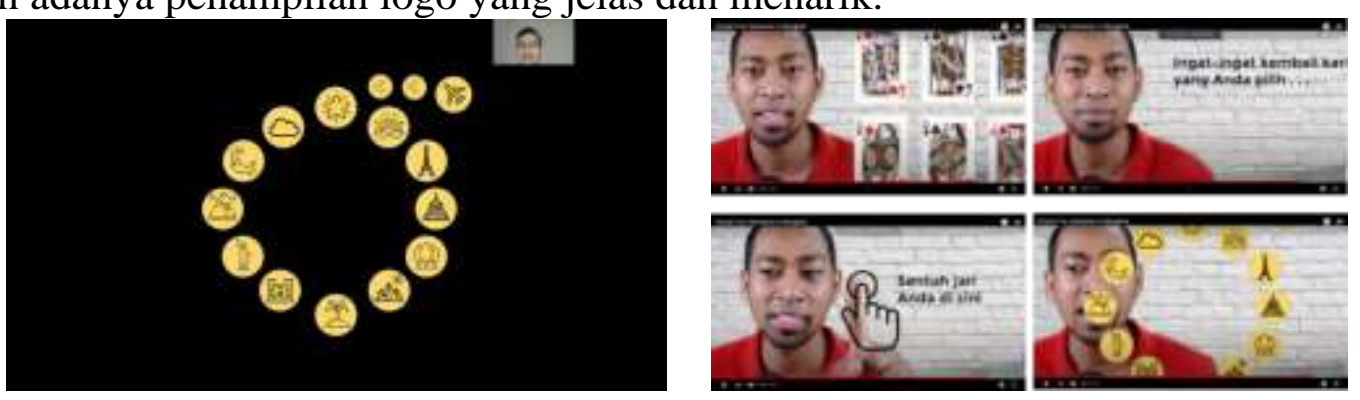

Gambar 5. Logo dalam Games Interaktif Virtual Tour

\subsubsection{Theoritical dan Proposed Research Framework}

Theoretical Acceptance Model (TAM) merupakan ilmu yang mempelajari bagaimana pengguna dapat menerima suatu teknologi yang menerangkan bagaimana pengaruh antara attitudes, beliefs dan final system (Lee, 2010). Tujuan dari TAM adalah untuk mengevaluasi bagaimana dampak karakteristik sistem terhadap keinginan konsumen (user-intention) (Lee, 
2010). TAM menggunakan dua model teori yaitu Perceived Ease-of-Use (PEOU) dan Perceived-Usefulness (PU). PEOU dan PU biasa digunakan untuk menjelaskan bagaimana pengaruh acceptance behavior dari pengguna terhadap teknologi (Surendran, 2012). PEOU mengimplikasikan bagaimana pengalaman penggunaan teknologi menjadi lebih mudah (ibid.). PU mengimplikasikan bagaimana perspektif pengguna dalam menggunakan teknologi untuk memaksimalkan performa kehidupan mereka (ibid.)

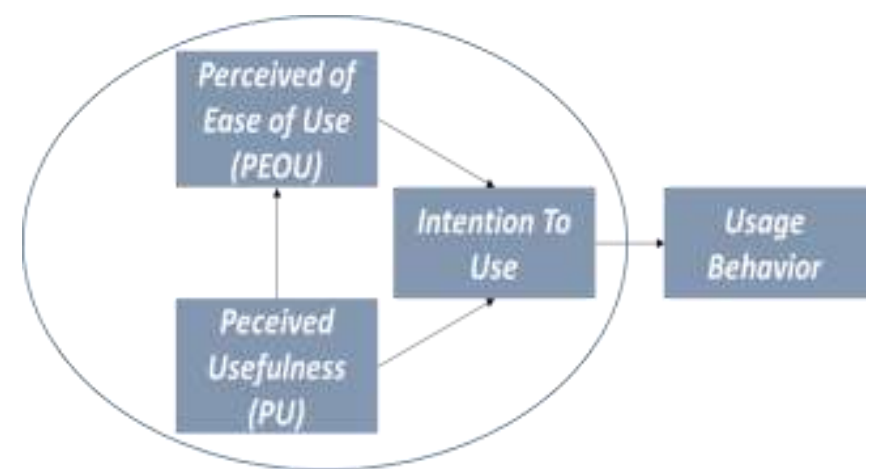

Gambar 6. Modifikasi Theoretical Acceptance Model (TAM)

Huang Y-C et al (2013) menggunakan TAM dalam penelitian untuk melihat hubungan antar elemen dalam 3D virtual digital kepada keinginan konsumen dalam menggunakan teknologi tersebut. PE dan PEOU diwakilkan dengan faktor enjoyment, emotional involvement, positive emotions dan flow experience (Huang Y.-C, 2013; Kim et al., 2018). Dalam penelitiannya, ditemukan bahwa PU dan PEOU memiliki pengaruh positif dalam meningkatkan keinginan konsumen dalam menggunakan fitur Virtual Tourism. Industri pariwisata butuh memperhatikan faktor PU dan PEOU terutama elemen enjoyment dan flow experience sehingga dapat menimbulkan keinginan untuk menggunakan Virtual Tourism (ibid.). Berdasarkan pembahasan dalam landasan teori, enjoyment, entertainment dan education menjadi elemen yang mampu menggambarkan kemudahan pengguna dalam menggunakan teknologi, dalam hal ini adalah Perceived Ease of Use (PEOU). Sedangkan, flow dan design background, berperan dalam memberikan pengguna petunjuk dalam penggunaan sehingga konsumen dapat mengikuti navigasi yang diberikan dalam Virtual Tourism.

Pada penelitian ini, peneliti fokus untuk mengetahui apa saja elemen yang dapat menimbulkan keinginan dari wisatawan untuk mencoba menggunakan Virtual Tourism. Jelas, bahwa faktor enjoyment dan flow experience memiliki pengaruh positif terhadap emotional involvement dan positive emotions wisatawan sehingga mempengaruhi keinginan konsumen dalam mencoba Virtual Tourism (Jung et al., 2017; Wagler et al., 2018). Namun, dibutuhkan penelitian khusus apakah faktor entertainment, design background dan edukasi menjadi faktor penting agar wisatawan lokal dan mancanegara mencoba Virtual Tourism. Selain itu, penelitian ini dibutuhkan untuk membuktikan apakah enjoyment dan flow experience tetap menjadi faktor signifikan yang mampu mempengaruhi tourist's intention dalam mencoba Virtual Tourism di Indonesia.

Teori framework yang diajukan sebagai berikut: 


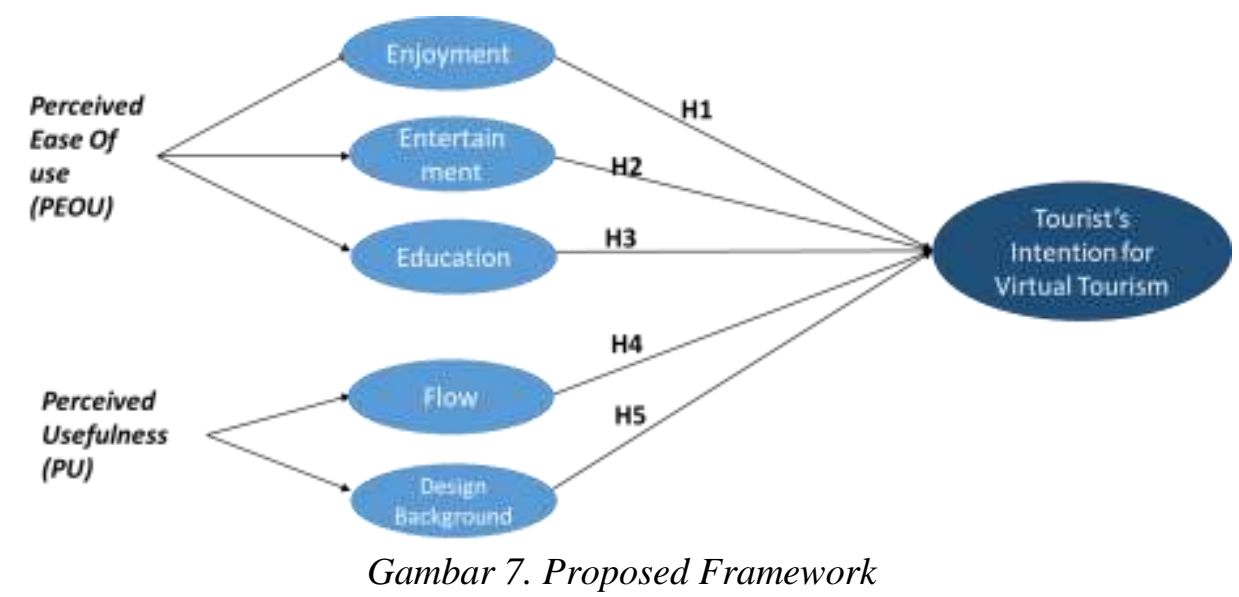

\subsubsection{Hipotesis}

Berdasarkan studi literatur yang membahas mengenai enjoyment dalam Virtual (Sylaiou et al., 2010; Goh et al., 2011; Huang Y.-C., 2013; Disztinger, et al., 2017; Wagler et al., 2018; Tussyadiah et al., 2018; Shafer et al., 2019; Gonza'lez-Rodrı'guez et al., 2020); dapat disimpulkan bahwa enjoyment merupakan aspek penting dalam pengalaman Virtual Tourism yang mampu membawa unsur fun. Namun, butuh dilihat bagaimana pengaruh langsungnya dengan tourist's intention dalam Virtual Tourism di Indonesia.

\section{H1 : Enjoyment dalam Virtual Tourism memiliki pengaruh langsung secara positif untuk meningkatkan atensi wisatawan menggunakan Virtual Tourism}

Entertainment berpengaruh erat untuk menstimulasi wisatawan dalam virtual sehingga tercapainya unsur hiburan. Penelitian sebelumnya, membahas bagaimana entertainment mampu menjadi unsur pendorong dalam keinginan menggunakan digital tourism (Guttentag, 2010; Besciu, 2013; Huan Y.-C, 2013; Njafipour et al., 2014; Huang Y. C. et al., 2016; Schaffer et al., 2018; The Jakarta Post, 2020; Maranti, 2020; Yuce et al., 2020). Namun, butuh dilihat bagaimana pengaruh langsung dengan tourist's intention dalam Virtual Tourism di Indonesia.

\section{H2 : Entertainment dalam Virtual Tourism memiliki pengaruh langsung secara positif untuk meningkatkan atensi wisatawan menggunakan Virtual Tourism}

Berdasarkan literatur berikut (Singh et al., 2008; Huang et al., 2010; Hsu et al., 2012; Zarzuela M. M. et al., 2013; Najafipour et al., 2014; Tussyadiah et al., 2017; Future Market Insights, 2020; Pestek et al., 2020), faktor education memiliki peran penting dalam mendorong peningkatan pengetahuan dalam digital. Dalam penelitian ini, peneliti ingin melihat pengaruh antar education terhadap tourist's intention dalam Virtual Tourism. Peneliti akan memperhatikan kesamaan informasi yang diberikan kepada audience serta memperhatikan unsur teknologi dengan mengutamakan mobile friendly. Peneliti akan menggunakan video yang sama sebagai sampel agar seluruh audiens memiliki informasi Virtual Tourism yang sama.

\section{H3 : Education dalam Virtual Tourism memiliki pengaruh langsung secara positif untuk meningkatkan atensi wisatawan menggunakan Virtual Tourism}

Peran flow dalam digital dijelaskan dalam beberapa literatur sebagai navigasi penting (Osman et al., 2009; Guttentag, 2010; Jursa, 2010; Marcus, et al., 2010; Huang Y.-c. , 2011; Hyun et al., 2012; Treder, 2013; Adriyanto et al., 2015; Samuely, 2016; Jung et al., 2017; Roth, 2017). Dalam penelitian kali ini, peneliti akan fokus terhadap bagaimana 
penting unsur Flow dalam Virtual Tourism agar pengunjung mau mencoba kembali Virtual Tourism.

\section{H4 : Flow dalam Virtual Tourism memiliki pengaruh langsung secara positif untuk meningkatkan atensi wisatawan menggunakan Virtual Tourism}

Pengertian mengenai Design Content Marketing (DMC) erat kaitannya dengan aesthetic dan unsur simbol lainnya yang tersusun sehingga menjadikannya unsur penting dalam digital yang pada penelitian ini peneliti sebut sebagai design background (Darejeh et al., 2013; Cao et al., 2015; Adytio et al., 2017; Yuliana et al., 2017). Pada penelitian kali ini, peneliti ingin melihat bagaimana pengaruh antar design background dengan keinginan wisatawan dalam mengikuti pengalaman Virtual Tourism. Maka dari itu hipotesis sebagai berikut:

\section{H5 : Design background dalam Virtual Tourism memiliki pengaruh langsung secara positif untuk meningkatkan atensi wisatawan menggunakan Virtual Tourism}

\section{METODOLOGI PENELITIAN}

Penelitian ini menggunakan metode kuantitatif, dengan menyebarkan survei kuesioner untuk mengetahui apa saja faktor terpenting yang mempengaruhi pengguna dalam menggunakan Virtual Tourism. Metode secondary data mengacu pada literatur yang telah dilakukan mengenai teknologi industri 4.0 serta pengaplikasiannya pada Virtual Tourism untuk mengatasi pandemi COVID-19 menggunakan sumber yang terpecaya yaitu PubMed, SCOPUS, Google Scholar dan Research Gate (Collis \& Hussey, 2014).

Peneliti mengadopsi positivist point-of-view, dimana peneliti yakin bahwa akan ada justifikasi rasional untuk memprediksi faktor apa saja yang mempengaruhi pentingnya Virtual Tourism untuk masyarakat dimana fenomena sosial bisa diukur, Positivism berasosiasi dengan metode kuantitatif berdasarkan analisis statistikal bentuk angka. Selanjutnya, penelitian ini mengadopsi konsep deductive-reasoning, dimana konsep dan teori telah direncanakan terlebih dahulu lalu dibuktikan dalam penelitian yang empiris (Collis \& Hussey, 2014). Peneliti mengaplikasikan analytical-survey method utuk mendapatkan primary data, bertujuan untuk menentukan apakah ada pengaruh antar variabel yang diuji (Collis \& Hussey, 2014, p. 63).

Peneliti fokus mengambil sampel populasi responden yang berdomisili di kota besar di Indonesia seperti Jakarta dan Tangerang dalam rentang umur milenial angkatan kerja yaitu 2029 tahun sebanyak 1.113.691 (Putra, 2020). Multivariative testing diimplementasikan sebelum penyebaran survei kuesioner melalui google form untuk menguji hipotesis dan kesesuaian target sampel (Collis \& Hussey, 2014). Penarikan data kepada sampel menggunakan quota sampling, non-probability sampling. Dimana, peneliti telah menentukan target jumlah sampel dengan karakteristik dan persyaratan sesuai dengan deskripsi sampel responden serta sesuai dengan multivariative testing (Collis \& Hussey, 2014). Asumsi persyaratan proporsi sampel diajukan karena kemudahan akses untuk menjangkau responden di kota besar. Selain itu, rentang usia milenial angkatan kerja diasumsikan telah memiliki pendapatan walaupun bentuknya hibah dari orang tua. Sampel ini dianggap mampu mencerminkan responden mandiri yang mampu membuat putusannya sendiri terutama dalam penggunaan dana serta memahami bagaimana menggunakan teknologi lebih mudah.

Peneliti menggunakan closed-ended questions agar lebih efisien waktu dan terfokus pada elemen. Survei menggunakan output 5 -point-liker-scale $(1=$ sangat tidak setuju, $5=$ sangat setuju) untuk membantu peneliti memahami masukan dari responden dengan baik (Collis \& 
Hussey, 2014). Peneliti menggunakan metode self-administered menggunakan kuesioner online yang dikirim melalui web-based kuosiner dan aktif selama 2-3 minggu.

Peneliti menggunakan simulasi video Virtual Tourism yang mengandung 5 (lima) kriteria yaitu; (1) Enjoyment, (2) Entertainment, (3) Education, (4) Flow dan (5) Design background yang sesuai dengan tinjuan pustaka (Lampiran 1). Responden diarahkan untuk menonton video Virtual Tourism sehingga setiap responden dipastikan telah memiliki kesamaan presepsi mengenai bagaimana pengalaman dalam mengikuti Virtual Tourism, sehingga pemahaman mengenai konteks mampu disampaikan dengan baik (Lampiran 2).

Peneliti mengimplementasikan multiple linear regression untuk mengestimasi hubungan antar lima variabel independen dan satu variabel dependen (Collis \& Hussey, 2014) serta menggunakan platform pemrograman Jupyter Notebook dengan bahasa pemograman phython untuk memproses data yang didapatkan dalam penelitian. Selain itu, untuk menghindari permasalahan distribusi dan trade mark, peneliti bekerjasama dengan pihak virtual pariwisata yaitu Perusahaan Virtual Tourism untuk menyediakan dan membuatkan materi Virtual Tourism yang interaktif. Selain video kerjasama, peneliti menggunakan video yang berasal dari kanal YouTube Kemenparekraf (Kementrian Pariwisata dan Ekonomi Kreatif) serta video dari beberapa YouTube creator. Seluruh video yang digunakan dalam penelitian simulasi video Virtual Tourism tetap mencantumkan sumber asli untuk menghargai creator serta menghindari permasalahan distribusi dan trade mark.

\section{HASIL PENELITIAN DAN DISKUSI}

\subsection{HASIL}

Pada awal penelitian, peneliti melakukan multivariative testing kepada 5 responden sebagai sample untuk mendapatkan feedback dan menghindari adanya duplikasi, kesamaan serta salah pengertian dari pertanyaan yang akan disampaikan kepada para reponsen dalam kuesioner aktual. Setelah revisi, tim peneliti menggunakan sosial media, civitas academic, referral dan komunikasi langsung untuk menyebarkan kuesioner tersebut selama 2 minggu dan berhasil mendapatkan 308 responden

Tabel 1. Usia

\begin{tabular}{|c|c|c|}
\hline Usia & n & Percentage \\
\hline $18-24$ & 244 & $79 \%$ \\
\hline $25-34$ & 30 & $10 \%$ \\
\hline Di bawah 18 tahun & 17 & $6 \%$ \\
\hline $35-44$ & 12 & $4 \%$ \\
\hline $45-54$ & 5 & $2 \%$ \\
\hline
\end{tabular}

Tabel 2. Lokasi Domisili

\begin{tabular}{|c|c|c|}
\hline Lokasi Domisili & $\mathbf{n}$ & Percentage \\
\hline Tangerang & 68 & $22.08 \%$ \\
\hline DKI Jakarta & 44 & $14.29 \%$ \\
\hline
\end{tabular}

\subsubsection{Descriptive Statistic}

Penghitungan central tendency and penghitungan penyebaran:

Tabel 4. Descriptive Tabel

\begin{tabular}{|c|c|c|c|c|c|c|}
\hline & $\begin{array}{c}\text { Continuance } \\
\text { purchase } \\
\text { intention }\end{array}$ & $\begin{array}{c}\text { Enjoymen } \\
\mathbf{t}\end{array}$ & $\begin{array}{c}\text { Entertainmen } \\
\mathbf{t}\end{array}$ & Education & Flow & $\begin{array}{c}\text { Design } \\
\text { backgroun } \\
\mathbf{d}\end{array}$ \\
\hline
\end{tabular}

Tabel 3. Pekerjaan

\begin{tabular}{|l|r|r|}
\hline \multicolumn{1}{|c|}{ Pekerjaan } & \multicolumn{1}{c|}{ n } & \multicolumn{2}{c|}{ Percentage } \\
\hline Mahasiswa & 236 & $77 \%$ \\
\hline Pelajar & 24 & $33 \%$ \\
\hline Karyawan swasta & 21 & $44 \%$ \\
\hline
\end{tabular}




\begin{tabular}{|c|c|c|c|c|c|c|}
\hline count & 309.000 & 309.000 & 309.000 & 309.000 & 309.000 & 309.000 \\
\hline mean & 4.099 & 4.188 & 4.228 & 4.286 & 4.125 & 4.453 \\
\hline std & 0.780 & 0.808 & 0.758 & 0.689 & 0.697 & 0.535 \\
\hline min & 1.000 & 1.000 & 1.500 & 1.250 & 1.200 & 1.500 \\
\hline $\mathbf{2 5 \%}$ & 3.667 & 4.000 & 4.000 & 4.000 & 3.800 & 4.000 \\
\hline $\mathbf{5 0 \%}$ & 4.333 & 4.000 & 4.500 & 4.250 & 4.200 & 4.667 \\
\hline $\mathbf{7 5 \%}$ & 4.667 & 5.000 & 5.000 & 5.000 & 4.600 & 4.833 \\
\hline max & 5.000 & 5.000 & 5.000 & 5.000 & 5.000 & 5.000 \\
\hline
\end{tabular}

Penelitian ini memiliki standar deviasi yang rendah dengan seluruh angka berada di bawah 1 dan di atas 0 . Semakin dekat standar deviasi dengan 0 mengartikan bahwa data yang dimiliki merupakan data yang mampu diandalkan (reliable). Berdasarkan nilai means, dapat dilihat bahwa responden mengisi jawaban paling tinggi pada pilihan predictor yaitu "sangat setuju" dan "setuju", dengan 4 (empat) dan 5 (lima) sebagai jawaban yang dominan.

(a)

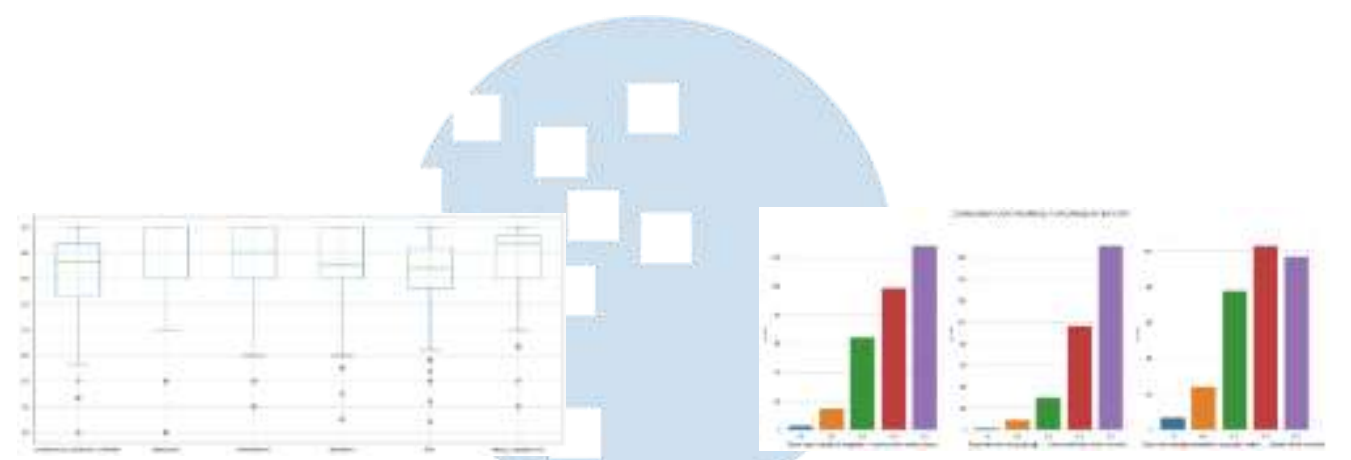

Barchart of Continuance Purchase Intention

Gambar 8. (a) Box and Whisker Plot dan (b)

\subsubsection{Distribusi Normal}

(a)

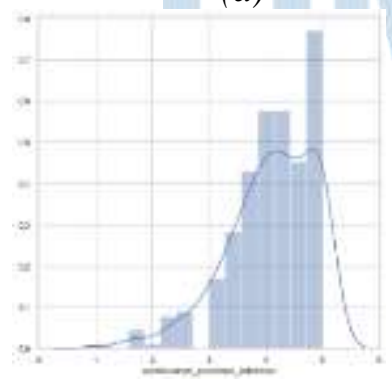

(b)

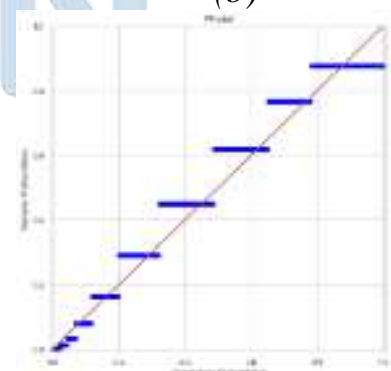

Gambar 9. (a) Histogram plot with KDE of Continuance Purchase Intention. (b) Probability plot of Continuance Purchase Intention

Uji Skewness dilakukan untuk mengetahui skor Z dari Continuance Purchase Intention. Hasilnya ditunjukkan pada Tabel 5. Untuk mengetahui apakah dataset telah diambil dari populasi terdistribusi normal, Uji Normalitas (D'Agostino dan Pearson's) dilakukan. Hasilnya ditunjukkan pada Tabel 6.

Tabel 5. Skewness Test Result Tabel 6. D'Agostino and Pearson's Normality Test

Result

\begin{tabular}{|l|l|}
\hline$Z$ Score & -5.892 \\
\hline P value & $3.797 \mathrm{e}-09$ \\
\hline
\end{tabular}

\begin{tabular}{|l|l|}
\hline P value & $1.442 \mathrm{e}-09$ \\
\hline
\end{tabular}


Karena nilai P berada di bawah nilai uji signifikansi (alpha $=0,05)$, maka hipotesis nol dapat ditolak (Distribusi Normal).

\subsubsection{Pearson Correlation and Sigma 2 tailed}

Uji pengaruh Pearson dilakukan untuk mengetahui nilai pengaruh dan nilai $\mathrm{p}$ dua arah untuk semua variabel. Hasilnya dapat dilihat pada Tabel 7.

Tabel 7. Pearson Correlation Tabel

\begin{tabular}{|c|c|c|c|c|c|c|}
\hline & $\begin{array}{c}\text { Continuance } \\
\text { Purchase } \\
\text { Intention }\end{array}$ & Enjoyment & Entertainment & Education & Flow & $\begin{array}{c}\text { Design } \\
\text { Background }\end{array}$ \\
\hline $\begin{array}{c}\text { Continuance } \\
\text { Purchase } \\
\text { Intention }\end{array}$ & 1.000 & 0.577 & 0.631 & 0.722 & 0.718 & 0.589 \\
\hline Enjoyment & 0.577 & 1.000 & 0.735 & 0.715 & 0.681 & 0.510 \\
\hline Entertainment & 0.631 & 0.735 & 1.000 & 0.715 & 0.745 & 0.536 \\
\hline Education & 0.722 & 0.715 & 0.715 & 1.000 & 0.778 & 0.675 \\
\hline Flow & 0.718 & 0.681 & 0.745 & 0.778 & 1.000 & 0.641 \\
\hline $\begin{array}{c}\text { Design } \\
\text { Background }\end{array}$ & 0.589 & 0.510 & 0.536 & 0.675 & 0.641 & 1.000 \\
\hline
\end{tabular}

Nilai $\mathrm{P}$ dua arah dari prediktor terhadap respons ditunjukkan pada Tabel 8.

Tabel 8. Nilai $P$ dua arah dari prediktor terhadap respons

\begin{tabular}{|c|c|c|}
\hline Predictor & Response & Two-tailed P-value \\
\hline Enjoyment & 0.000 \\
\hline Entertainment & \multirow{3}{*}{ Continuance Purchase } & 0.000 \\
\hline Education & Intention & 0.000 \\
\hline Flow & & 0.000 \\
& & 0.000 \\
\hline Design Background & & \\
& &
\end{tabular}

Semua prediktor memiliki $p$-value signifikan $(p-$ value $<0,05)$. Pengaruh pearson tertinggi antara prediktor dan respon ditemukan pada Education - Continuance Purchase Intention (0,722), diikuti oleh Flow - Continuance Purchase Intention $(0,718)$.

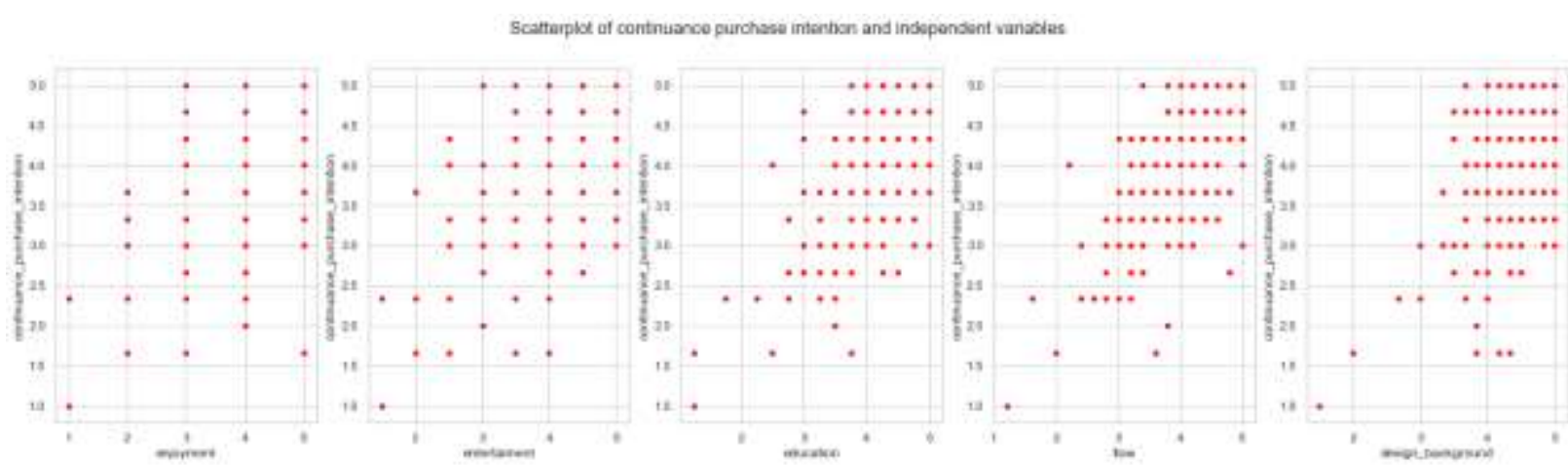

Gambar 10. Scatterplot of Continuance Purchase Intention and Independent Variables

\subsubsection{ANOVA}

Untuk menganalisis ANOVA, pertama variabel independen disesuaikan dengan model regresi berganda. Arsitektur model ditunjukkan pada gambar 11. Hasil atau ringkasan dari regresi di atas ditunjukkan pada gambar 12 . 


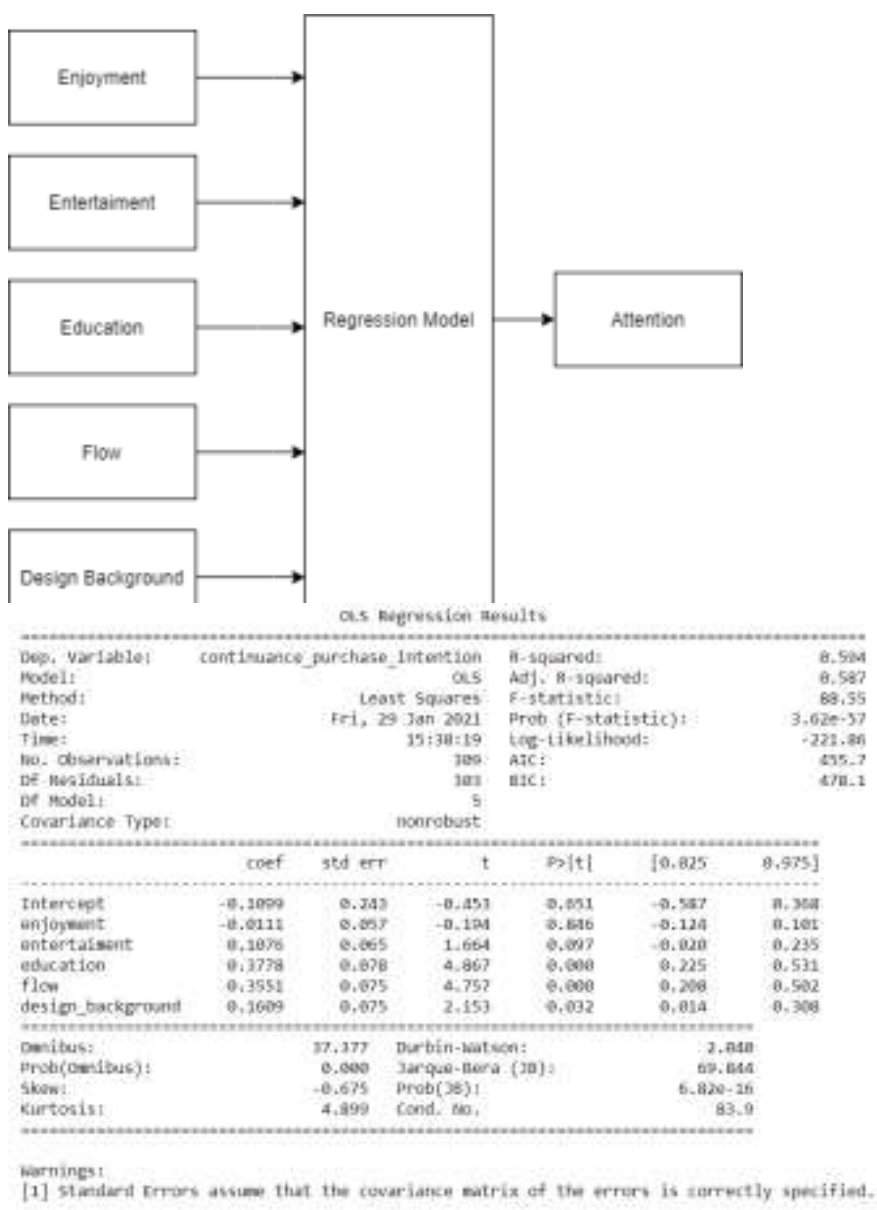

Gambar 11. Multiple Regression Model

Gambar 12. Regression Result

Hasil F-test untuk model regresi ditunjukkan pada Tabel 8 berikut:

Tabel 9. Hasil Uji-F untuk Model Regresi

\begin{tabular}{|c|c|}
\hline F Statistics & 88.55 \\
\hline P Value & $3.62 \mathrm{e}-57$ \\
\hline
\end{tabular}

Tabel 9 mencetak probabilitas kemunculan F-statistik dengan asumsi bahwa hipotesis nol adalah benar (null hypothesis is true). $P$ - value yang menunjukkan bahwa 3,62e - 57 yang lebih kecil dari alpha $(0,05)$. Dengan demikian, terdapat kemungkinan yang jauh lebih kecil dari 5\% bahwa F-statistik 88,55 dapat terjadi secara kebetulan dengan asumsi hipotesis nol yang valid. Artinya, model tersebut dapat menjelaskan varians pada variabel dependen dengan lebih baik daripada model intercept-only.

Dilakukan ANOVA per prediktor dan hasilnya ditunjukkan pada Tabel 9:

Tabel 10. ANOVA per Predictors

\begin{tabular}{|c|c|c|c|c|}
\hline & Sum of Square & Degree of Freedom & F Score & P Value (PR (> F)) \\
\hline Enjoyment & 62.273 & 62.273 & 248.099 & 0.000 \\
\hline Entertainment & 17.382 & 17.382 & 69.251 & 0.000 \\
\hline Education & 22.990 & 22.990 & 91.595 & 0.000 \\
\hline Flow & 7.316 & 7.316 & 29.149 & 0.000 \\
\hline Design background & 1.163 & 1.163 & 4.635 & 0.032 \\
\hline
\end{tabular}




\begin{tabular}{|l|l|l|l|l|}
\hline Residual & 76.053 & 0.251 & & \\
\hline
\end{tabular}

Tabel 10 menunjukkan bahwa masing-masing prediktor memiliki nilai signifikan. Artinya terdapat perbedaan yang signifikan secara statistik antara kelompok dan pengaruhnya.

ANOVA satu arah antara garis regresi dan data aktual (variabel dependen) juga dilakukan, hasilnya ditunjukkan pada Tabel 11:

Tabel 11. ANOVA one way between Regression Line and Dependent Variable

\begin{tabular}{|c|c|}
\hline F one-way statistics & $2.842 \mathrm{e}-28$ \\
\hline P value & 1.0 \\
\hline
\end{tabular}

$P$ - value $>0.05$, yang berarti tidak ada perbedaan selisih antara garis regresi dengan data aktual (variabel terikat) yang berarti garis regresi dapat menjelaskan varians tersebut.

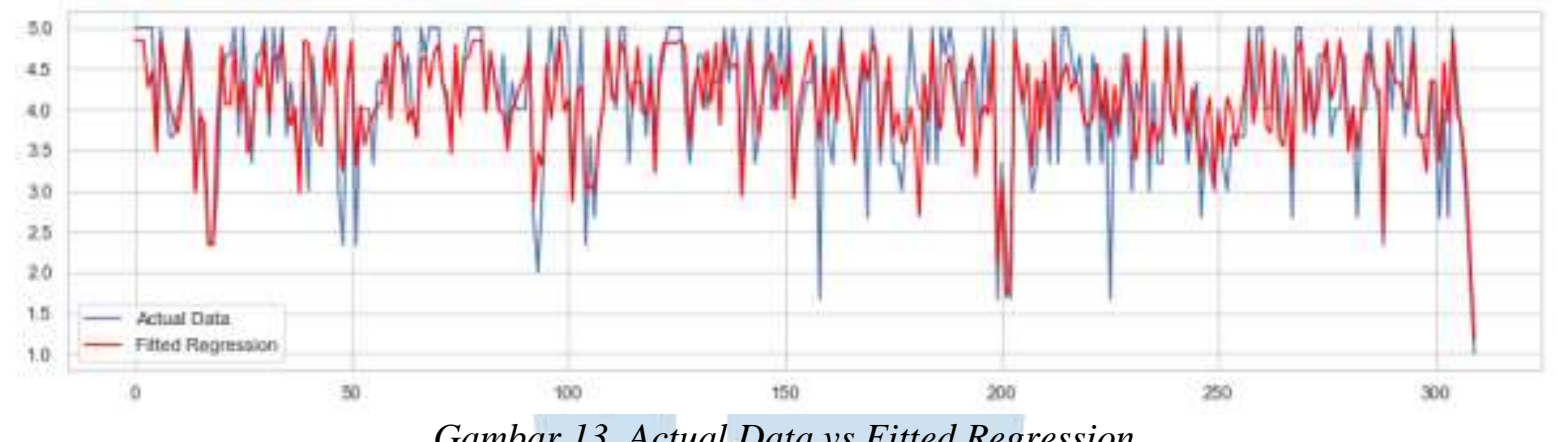

\subsubsection{Model Summary or Goodness of Fit}

Goodness of fit model multi regresi dijelaskan dengan $\mathrm{R}$ kuadrat dan Adjusted $\mathrm{R}$ kuadrat pada Tabel 12.

Tabel 12. R squared and Adjusted R squared of Regression Model

\begin{tabular}{|c|c|}
\hline R squared & 0.594 \\
\hline Adjusted R Squared & 0.587 \\
\hline
\end{tabular}

$\mathrm{R}$ kuadrat model regresi lebih besar dari 0,5 , artinya model regresi berganda cocok untuk memprediksi hasil sama dengan nilai R-kuadrat.

\subsubsection{Tabel of Coefficient}

Multikolinieritas dalam beberapa model regresi prediktor ditunjukkan pada Tabel 13. Tabel 12 menunjukkan bahwa terdapat multikolinieritas yang tinggi antar prediktor. Nilai multikolinearitas tertinggi dimiliki oleh variabel Pendidikan.

Tabel 13. Multiple Regression Predictor's VIF

\begin{tabular}{|c|c|}
\hline Variables & VIF \\
\hline Enjoyment & 73.111 \\
\hline Entertainment & 94.165 \\
\hline Education & 139.771 \\
\hline Flow & 120.017 \\
\hline Design Background & 83.504 \\
\hline
\end{tabular}

Pengaruh positif atau negatif variabel independen dalam koefisien regresi beserta nilai p-nya ditunjukkan pada Tabel 14. 
Tabel 14. Positive and Negative Correlation

\begin{tabular}{|c|c|c|}
\hline Variables & Coefficient & P Value \\
\hline Enjoyment & -0.011 & 0.846 \\
\hline Entertainment & 0.108 & 0.097 \\
\hline Education & 0.378 & 0.000 \\
\hline Flow & 0.356 & 0.000 \\
\hline Design Background & 0.161 & 0.032 \\
\hline
\end{tabular}

Tabel 12 menyimpulkan bahwa enjoyment dan entertainment tidak signifikan secara statistik dan hasil ini mendukung bahwa variabel-variabel ini mungkin tidak memiliki pengaruh yang signifikan dengan niat beli berkelanjutan karena p-value melebihi nilai alpha $(p-$ value $>0,05)$. Di sisi lain, education, flow dan design background signifikan secara statistik dan berpengaruh positif dengan niat beli berkelanjutan karena $p$-value berada di bawah nilai alpha $(p-$ value $<0,05)$. Design background merupakan elemen terpenting yang mempengaruhi keinginan seseorang untuk mengikuti kembali Virtual Tourism dengan nilai $p$-value tertinggi yaitu $0.032<0.05$. Unsur Education dan flow memiliki kepentingan yang setara dengan $p-$ value $=0.000<0.05$.

\subsection{Diskusi}

Berdasarkan analisis data, dapat disimpulkan hasil research framework sebagai berikut:

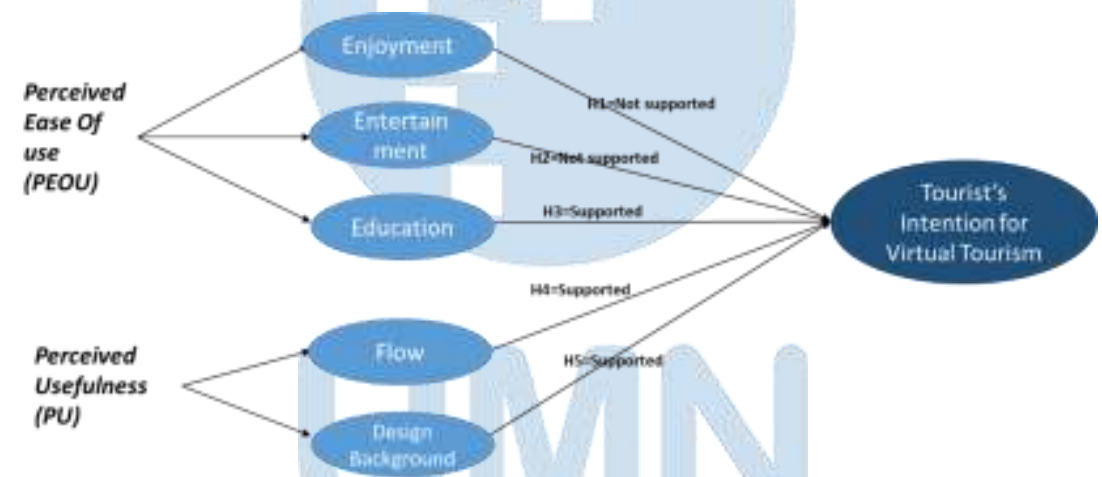

Gambar 14. Reserach framework and value scores

\subsubsection{Diskusi Hipotesis 1}

Berdasarkan hasil kalkulasi hitungan dalam penelitian ini, elemen enjoyment tidak mendukung atensi wisatawan dalam mengikuti Virtual Tourism, dengan nilai $H 1=0.846$. Enjoyment merupakan faktor yang meliputi kompetensi, autonomi dan pengaruh (Huang Y.-C, 2018). Untuk mencapai enjoyment, dipengaruhi oleh faktor eksternal yang tak terkendali seperti iklim dan cuaca yang tidak dapat dirasakan secara langsung oleh wisatawan ketika mengikuti Virtual Tourism karena perbedaan waktu dan lokasi. Wisatawan mengikuti Virtual Tourism dari rumah masing-masing secara daring, sehingga sudah pasti terdapat perbedaan lokasi antara satu sama lain atau bahkan perbedaan waktu apabila wisatawan tinggal di daerah dengan zona waktu yang berbeda dengan penyelia Virtual Tourism. Kondisi iklim dan cuaca yang berbeda-beda tentu mempengaruhi mood atau suasana wisatawan ketika mengikuti Virtual Tourism. Misalnya ketika melakukan Virtual Tourism, cuaca di tempat tinggal wisatawan saat itu agak panas sehingga membuat wisatawan jadi kurang fokus dan tidak nyaman ketika mengikuti Virtual Tourism. Akibatnya, pengalaman enjoyment tidak dapat 
tercapai karena iklim dan cuaca pada saat itu membuat suasana jadi kurang kondusif (Wagler \& Hanus, 2018).

Faktor keramahan dan pelayanan yang diberikan secara langsung, tidak mampu diakomodasi oleh internet (Gonza'lez-Rodri'guez et al., 2020). Wisatawan mengikuti Virtual Tourism dari tempat tinggalnya masing-masing, sehingga keramahan dan pelayanan yang idealnya dirasakan secara langsung di destinasi wisata tidak dapat dirasakan. Keterbatasan interaksi dan pilihan aktivitas yang dapat diikuti wisatawan juga menjadi faktor lain yang menyebabkan sulitnya menyampaikan enjoyment kepada para wisawatan, karena wisatawan tidak dapat melakukan interaksi secara langsung dengan lingkungan yang berada disekitar destinasi wisata ataupun mencoba aktivitas yang hanya tersedia di destinasi tersebut.

\subsubsection{Diskusi Hipotesis 2}

Berdasarkan penelitian yang dilaksanakan, entertainment tidak memiliki pengaruh signifikan terhadap atensi wisatawan menggunakan Virtual Tourism dengan nilai $\mathrm{H2}=$ 0.097. Hal ini terjadi karena manusia adalah makhluk visual, oleh karena itu dalam entertainment membutuhkan perangkat yang mampu menimbulkan fantasi sehingga pengunjung merasakan hiburan (Najafipour et al., 2014; Yuce et al., 2020). Namun hasil penelitian ini menunjukkan bahwa perangkat yang tersedia seperti Google Arts and Culture, Google Maps Street View, 360 derajat video views, LIVE conversation, dan video belum mampu menimbulkan unsur hiburan kepada para pengguna Virtual Tourism. Perjalanan wisata yang diikuti melalui media 2D (baik secara live ataupun tidak), belum sepenuhnya mampu memberikan wisatawan rasa terhibur atau pengalaman yang unik dan berkesan.

Ketersediaan perangkat pendukung erat pengaruhnya dengan pertumbuhan teknologi VR di Indonesia. Walapun masyarakat Indonesia menyambut dengan antusiasme yang baik, hambatan dalam dana dan pengetahuan cara mengoptimalisasikannya dalam bidang Virtual Tourism belum optimum (Bakti Kominfo, 2019). Hal ini didukung dengan statement dari Nico Alyus, CEO Omni VR, "Satu unit VR lengkap saja harganya bisa mencapai Rp40 jutaan. Biasanya, VR diperuntukkan ke first world country" (Pramudita, 2019). Pandangan masyarakat yang fokus terhadap penggunaan VR untuk industri game dan menonton video, membuat peluang ide pengembangan VR untuk sektor industri lain menjadi terbatas dan terlupakan. Hal ini menjadikan perkembangan teknologi VR untuk Virtual Tourism di Indonesia belum maksimal (ibid.). Perangkat teknologi lain yang dapat menampilkan media dalam bentuk 3D (hologram) juga jarang digunakan sebagai salah satu media untuk melakukan Virtual Tourism.

\subsection{1}

\subsubsection{Diskusi Hipotesis 3}

Berdasarkan perhitungan, elemen edukasi mampu meningkatkan atensi wisatawan untuk menggunakan Virtual Tourism, dengan nilai $H 3=0.000$. Konsep edu-tourism menjadi asal-muasal dimana pengalaman wisata memiliki pengaruh yang dekat dengan konten edukasi (Future Market Insights, 2020). Kegiatan berwisata yang dibarengi dengan edukasi mengenai destinasi yang dituju meningkatkan rasa excitement dalam diri wisatawan untuk mengikuti perjalanan wisata agar dapat mengetahui dan mempelajari informasi menarik yang terdapat di destinasi tersebut. Memasukkan sejumlah edukasi didalam berwisata juga memberikan dampak positif terhadap minat masyarakat untuk mengikuti perjalanan wisata, karena masyarakat dapat merasakan manfaat berupa pengetahuan baru ketika melakukan kegiatan berwisata. Singh dan Lee (2008) menyatakan bahwa unsur edukasi 
mampu meningkatkan perasaan usefulness dan playfulness, sehingga berdampak kepada intention to use.

Educational tourism menjadi trend, ditandakan dengan meningkatnya permintaan wisawatan akan metode baru untuk berekreasi, dengan tujuan mempelajari destinasi tujuan wisata (Zarzuela et al., 2013). Virtual Reality (VR) sebagai salah satu digital media, mampu membangkitkan semangat belajar dan ingin tahu para wisatawan (ibid.). Pemerintah daerah yang tergabung dalam APEKSI (Asosiasi Pemerintah Kota Seluruh Indonesia) berkolaborasi dengan UCLG ASPAC yang didanai oleh Uni Eropa, membentuk program bernama LOCALISE SDG's yang bertujuan membantu pemerintah daerah Indonesia meningkatkan kapasitas dalam upaya pemulihan sektor pariwisata dalam berbagai kegiatan. Eksekusi digitalisasi sebagai implementasi tujuan 9 mengenai industri dan inovasi. Hasil yang kita lihat dengan dimulainya pembuatan konten kreasi mengenai edukasi tujuan wisata terkenal di Indonesia, salah satunya adalah PT. KA Wisata yang meluncurkan virtual tour lawang semu dan museum kereta api ambarawa yang menggabungkan marketing 5.0, sehingga wisatawan mampu membeli cindera mata yang dijual di lokasi tersebut dan akan langsung dikirimkan ke rumah (Abdullah, 2020; APEKSI, 2020; Localise SDG's, 2020; Mahardika, 2021). Hal ini menunjukkan bahwa kebutuhan akan keilmuan dan kolaborasi antar inovasi teknologi dan pariwisata menjadi daya tarik tersendiri untuk wisawatan mencoba kembali Virtual Tourism.

\subsubsection{Diskusi Hipotesis 4}

Berdasarkan analisis dalam penelitian ini, flow memiliki pengaruh langsung untuk meningkatkan atensi wisatawan dalam mengikuti Virtual Tourism dengan $H 4=0.000$. Flow sendiri erat kaitannya dengan bagaimana penyelia Virtual Tourism merancang acara dari awal hingga akhir serta bagaimana kemudahan pengunjung dalam mengikuti arahan dari pemandu wisata atau yang disimbolkan melalui menu logo dalam video tourism (Huang Y-C, 2011). Presentasi unsur flow yang baik selama perjalanan wisata berlangsung juga memberikan rasa kebersamaan kepada wisatawan. Wisatawan seakan-akan diajak secara langsung untuk berpetualang bersama ke destinasi wisata sehingga wisatawan tidak merasa kesepian atau feeling left out ketika mengikuti perjalanan wisata. Kesesuaian serta alur perjalanan wisata yang jelas dan teratur dari awal hingga akhir menjadi faktor yang mendorong wisatawan untuk mengikuti perjalanan wisata lagi dengan destinasi yang berbeda di kemudian hari.

Flow sangat berkaitan dengan UX. Dimana, para wisatawan telah memiliki ekspektasi di awal sebelum mengikuti Virtual Tourism mengenai timeline wisata serta penggunaan tombol yang ada di dalam Virtual Tourism (Marcus, et al., 2010; Adriyanto \& Triani, 2015). Dalam simulasi penelitian video Virtual Tourism, flow dilambangkan dengan pengenalan rute navigasi dan pengenalan bagaimana cara mengikuti instruksi symbol di awal wisata. Sehingga, wisatawan diedukasi terlebih dahulu mengenai apa yang akan mereka ikuti. Unsur tersebut memberikan menjadi penting bagi wisatawan karena menciptakan ketertarikan emosional yang menciptakan efek positif, dimana para pengguna memiliki ekspektasi mengikuti Virtual Tourism (Jung et al., 2017)

\subsubsection{Diskusi Hipotesis 5}

Berdasarkan penelitian, terbukti bahwa design background memiliki afirmasi positif terhadap atensi wisatawan dalam menggunakan Virtual Tourism, serta menjadi elemen paling berpengaruh dalam penelitian ini dengan nilai tertinggi yaitu $H 5=0.032$. Dalam Virtual Tourism, wisatawan tentunya mengikuti rangkaian perjalanan wisata hanya melalui media $2 \mathrm{D}$ 
seperti presentasi, video, gambar, teks, atau google map. Unsur design background yang informatif dan menarik pasti akan memberikan pengalaman unik bagi setiap wisatawan. Semakin menarik presentasi unsur design background, maka akan berdampak positif terhadap minat wisatawan untuk kembali mengikuti Virtual Tourism mengenai destinasi lainnya di kemudian hari. Oleh karena itu, design background menjadi faktor penting yang mempengarui sudut pandang wisatawan terhadap Virtual Tourism.

Sesuai dengan pengertian design background dalam secondary data research, design background memiliki keterikatan dengan unsur estetika serta UI. Bagaimana penyelia virtual tour mampu menyeimbangkan kombinasi dalam elemen teks, grafik, suara, video dan animasi (Adytio et al., 2017). Dalam simulasi video virtual tourism pada penelitian ini, jelas bahwa unsur design background yang mampu mempertahankan para wisatawan mengikuti pengalaman Virtual Tourism, terlebih penggabungan antar budaya lokal yang menjadi tema design UI menjadi cara lain untuk mengkomunikasikan apa yang akan dijelaskan kepada para wisatawan (Yuan et al., 2016). Komunikasi dua arah yang dilakukan oleh pemandu wisata yang disimbolkan dalam logo serta unsur yang menarik, membawa para penonton aktif dalam keseluruhan experience dalam simulasi video Virtual Tourism (Yuliana et al., 2017). Hal ini menekankan, bahwa keseimbangan dalam unsur UI mampu menjadi elemen yang diutamakan dalam eksekusi Virtual Tourism.

\section{KESIMPULAN, KETERBATASAN DAN SARAN 4.1 KESIMPULAN}

Penelitian ini membahas 5 (lima) unsur penting demi tercapainya pengalaman Virtual Tourism yang menyenangkan yaitu: (1) Enjoyment (Sylaiou et al., 2010; Huang Y.-C., 2013; Tussyadiah et al., 2018; Shafer et al., 2019), (2) Entertainment (Guttentag, 2010; Besciu, 2013; Yuce et al., 2020), (3) Education, (Singh et al., 2008; Tussyadiah et al., 2017; Pestek et al., 2020), (4) Flow (Huang Y.-c., 2011, Hyun et al., 2012; Samuely, 2016; Roth, 2017), dan (5) Design background (Cao et al., 2015; Adytio et al., 2017; Yuliana et al., 2017).

Mengimplementasikan dengan maksimal keseluruhan elemen tersebut membutuhkan biaya yang tidak sedikit serta waktu pengembangan yang lebih banyak. Sehingga, penyelia wisata terpecah fokusnya dan tidak memaksimalkan salah satu poin tersebut. Dibutuhkan skala prioritas dari kelima unsur di atas untuk dimaksimalkan dan dijadikan USP (Unique Selling Proposition) oleh penyelia wisata yang ingin membuka peluang Virtual Tourism.

Penelitian ini menggunakan metode kuantitatif dimana peneliti akan mengirimkan tautan kuesioner kepada responden melalui media google form. Sebelum mengisi lembar pertanyaan, responden diwajibkan untuk menonton video simulasi Virtual Tourism yang telah dilampirkan. Pada penelitian serupa, (Disztinger et al., 2017; Ekasaputri \& Aruan, 2018; El-Said et al., 2021) jarang ditemukan peneliti menyisipkan video Virtual Tourism dalam penelitiannya sehingga persepsi responden terhadap Virtual Tourism yang mengandung kelima unsur tersebut bisa jadi berbeda-beda. Maka dari itu, peneliti fokus dengan membuat dan mengemas video Virtual Tourism yang mengandung kelima unsur tersebut dalam penelitian. Sehingga, persepsi responden yang mengisi kuesioner mengenai Virtual Tourism mampu disamakan.

Berdasarkan hasil penelitian, unsur enjoyment dan entertainment tidak memiliki pengaruh terhadap continuance-intention consumer untuk menggunakan Virtual Tourism. Hal ini disebabkan karena responden mampu mendapatkan pengalaman kebahagiaan dan kesenangan melalui aktivitas lain di digital tanpa harus mengikuti Virtual Tourism (Bhojwani, 2020). Data menunjukkan bahwa selama pandemi COVID-19, pengguna YouTube dan aplikasi penyelia video berbayar lainnya seperti Disney+ Hotstar di Indonesia meningkat sehingga diasumsikan bahwa penyelia video tersebut mampu menjadi subtitusi enjoyment dan 
entertainment setara dengan pengalaman yang didapatkan melalui Virtual (Bhojwani, 2021).

Di sisi lain, design background, education dan flow terbukti memiliki pengaruh yang signifikan terhadap continuance-intention dalam menggunakan Virtual Tourism. Unsur design background menjadi faktor terpenting dalam Virtual Tourism. Konsumen merasa aesthetic yang dihadirkan dalam Virtual Tourism menjadi alasan mengapa mereka kembali. Elemen edukasi dan flow menjadi faktor pendukung yang mampu menjadi potensi unfair advantage untuk para industri yang bermain di pariwisata terutama yang telah mengimplementasikan Virtual Tourism, seperti Dwidaya dan Virtual Tourism.

\subsection{SARAN}

\subsubsection{IMPLIKASI MANAGERIAL}

Membicarakan mengenai teknologi, artinya kita tidak hanya membahas fenomena yang terjadi pada masa lampu dan sekarang, namun prediksi yang akan terjadi di masa depan terutama yang berkenaan dengan pengembanan teknologi khususnya pada penelitian ini. Setiap industri dituntut untuk agile dan beradaptasi dengan kondisi serba terbatas yang terjadi selama pandemi. Salah satunya adalah industri pariwisata yang erat dengan pengalaman langsung wisatawan dengan tempat tujuan. Tantangan utama nya adalah bagaimana membawa unsur intangible menjadi unsur tangible sehingga masyarakat mampu membayangkan hadir di lokasi tujuan tanpa berinteraksi langsung dengan kerumunan (Gonza'lez-Rodri'guez et al., 2020). Virtual Tourism hadir menjadi solusi namun masih belum mutakhir karena perkembangan teknologi tidak merata serta start-up dana yang begitu tinggi (Suryanto, 2021). Menimbulkan riskiest assumption yang tak terbantahkan.

Penelitian ini memberikan masukan kepada para pemain industri pariwisata dan pemerintah terutama Kementrian Pariwisata dan Ekonomi Kreatif Republik Indonesia (Kemenparekraf) dalam mengemas potensi Virtual Tourism di Indonesia. Para pegusaha wisata mampu menggunakan existing consumer data mereka untuk memasarkan fasilitas Virtual Tourism yang mengedepankan unsur design, keilmuan dan flow sehingga para wisatawan mampu immerse ke dalam pengalaman tersebut.

Selain itu, para pemain industri wisata mampu mengandalkan koneksi warga lokal daerah wisata untuk bekerjasama memandu dan membuat konten menarik mengenai tujuan wisata mereka dan dikemas apik dalam Virtual Tourism (Kemenparekraf, 2021). Warga lokal tujuan wisata menjadi sumber ilmu untuk para wisatawan Virtual Tourism. Mereka juga mendapat kesempatan untuk menjual secara interaktif produk hasil pekerjaan tangan mereka, sehingga konsumen juga mampu mendapatkan kesempatan memiliki cendera mata asli tujuan wisata Virtual Tourism.

Implikasi managerial tersebut dapat berlaku untuk Kemenparekraf. Dalam akun kanal YouTubenya, jelas bahwa Kemenparekraf menaruh fokus terhadap Virtual Tourism dengan mem-posting konten berkenaan dengan tujuan kota wisata di Indonesia. Kemenparekraf mampu berkontribusi dengan menghubungkan koneksi antar warga lokal dengan industri wisawatan asing. Selanjutnya, mendorong inovasi tersebut ke dalam mengata Visit Indonesia. Sehingga, Indonesia tidak akan kehilangan daya tariknya di mata wisatawan lokal dan asing. Virtual Tourism yang dikemas dengan aesthetic mampu membawa para wisatawan untuk berkunjung paska pandemi COVID-19. Selain unsur aesthetic, gabungan antar unsur education dan flow mendorong ekonomi lokal daerah wisata, dengan menyediakan komunikasi dua arah mengenai informasi tujuan wisata serta kemudahan berbelanja cendera mata dari lokasi tersebut secara langsung, dibantu oleh pemandu wisata secara virtual. Dimana cindera mata tersebut akan dikirimkan ke rumah wisatawan (Marketing 5.0). 


\subsubsection{SARAN UNTUK PENELITIAN MASA DEPAN}

Penelitian selanjutnya membutuhkan sudut pandang warga lokal tujuan wisata mengenai penggunaan virtual tourism sebagai media perantara yang membantu dalam mendorong pertumbuhan industri tourism di Indonesia sebagai alternatif solusi selama pandemi, sehingga mampu diketahui apa saja elemen yang mampu dieksplorasi dari segi budaya dan pengembangan teknologi lokal yang tersedia. Dari segi wirausahawan, dibutuhkan feedback langsung mengenai implementasi virtual tourism sehingga cakrawala mengenai elemen penting dalam virtual tourism dapat sinergi dari segala bidang terkait. Terakhir, dibutuhkan evaluasi lebih lanjut untuk mengetahui efektifitas Marketing 5.0 dalam pengembangan sistem Virtal Tourism.

\subsubsection{LIMITASI}

Limitasi dalam penelitian ini meliputi:

1. Peneliti mengadaptasi lima unsur yaitu enjoyment, entertainment, education, flow dan design background.

2. Penelitian ini hanya memaksimalkan penggunaan simulasi video Virtual Tourism sebagai perantara simulasi dalam materi penelitian, dimana unsur komunikasi langsung dua arah yang terjadi dalam pariwisata tidak diimplementasikan dalam penelitian ini.

3. Penelitian ini hanya berfokus kepada continuance-intention consumer di Indonesia. Penelitian lebih lanjut dibutuhkan untuk beradaptasi kepada kebutuhan tertentu.

\section{REFERENCES}

Abdullah, T. (2020, April 4). Lockdown dan Virtual Tourism. Retrieved from Indonesian Tourism Review: https://www.itr.or.id/2020/04/04/lockdown-dan-virtual-tourism/

Adriyanto, A. R., \& Triani, A. R. (2015, September 8-9). 360 Virtual Reality Panorama of Indonesia Tourism. International Conference on Creative Industries, 2, 302-312. Retrieved August 7, 2020

Adytio, A., Niswar, M., \& Ilham, A. A. (2017). Pembuatan Virtual Reality Tour dengan Metode Gambar Panorama untuk Kampus Fakultas Teknik Universitas Hasanuddin. Universitas Hasanuddin, 1-11.

APEKSI. (2020, July 22). Leadership Ownership and Capabilities for Agenda 2030 Local Implementation and Stakeholder Empowerment. Retrieved from apeksi.id: https://apeksi.id/index.php/localisesdgs?start=10

Badan Koordinasi Penanaman Modal. (2020, August 7). Making Indonesia 4.0: Indonesia's Strategy to Enter the 4th Generation of Industry Revolution. Retrieved from Badan Koordinasi Penanaman Modal: https://www.investindonesia.go.id/en/whyinvest/indonesia-economic-update/making-indonesia-4.0-indonesias-strategy-to-enterthe-4th-generation-of-ind

BCC. (2018, April 30). Massive Virtual Reality Theme Park Opens In China. Retrieved August 7, 2020, from Blue Collar Comp: https://www.bluecollarcomp.com/massive-virtualreality-theme-park-opens-in-china/

Besciu, I. G. (2013). Behaviour of the consumer of tourist entertainment services. Cactus Journal, 4(2), 9-19. 
Bhojwani, Lavina;. (2021, January 19). Indonesia: Cumulative SVOD subscribers reach 7 mil., led by Disney+ Hotsta. Retrieved from Media Partners Asia: https://www.mediapartners-asia.com/article.php?id=2332

Cao, J., Kamil, Krzystof, \& Ellis, M. (2015). Web UI Design for the Human Eye. Colors, Space, Contrast. Retrieved from uxpin: https://www.uxpin.com/studio/ebooks/visual-web-uidesign-colors-space-contrast/

CNN Indonesia. (2020, February 2). Menghitung Kontribusi Sektor Pariwisata Bagi Ekonomi RI. Retrieved August 6, 2020, from CNN Indonesia: https://www.cnnindonesia.com/ekonomi/20200226121314-532-478265/menghitungkontribusi-sektor-pariwisata-bagi-ekonomi-ri

Coetzee, L., \& Eksteen, J. (2011). The Internet of Things - Promise for the Future? An Introduction. IST-Africa 2011 Conference Proceedings.

Collis, J., \& Hussey, R. (2014). Business Research: A Practical Guide for Undergraduate and Postgraduate students (Vol. 4). Cornwall: Palgrave Macmillan.

Deale, C. (2013). Incorporating Second Life into online hospitality and tourism education: A case study. Journal of Hospitality, Leisure, Sport \& Tourism Education, 154-160. doi:10.1016/j.jhlste.2013.09.002.

Ekasaputri, N., \& Aruan, D. T. (2018). The Effect of Virtual Reality on Behavioral Intention to Visit a Tourist Destination. The 4th International Conference on Management Sciences 2018 (ICoMS 2018). Retrieved from http://repository.umy.ac.id/bitstream/handle/123456789/18649/The\%20Effect\%20of $\% 20$ Virtual\%20Reality\%20on\%20Behavioral\%20Intention\%20to\%20Visit\%20a\%20 Tourist $\% 20$ Destination.pdf?sequence $=1 \&$ is Allowed $=\mathrm{y}$

Future Market Insights. (2020). Educational tourism: sector look. Dubai: Future Market Insights.

Goh, S., \& Yoon, T. (2011). If You Build It Will They Come? An Empirical Investigation of Facilitators and Inhibitors of Hedonic Virtual World Acceptance. Paper presented at the System Sciences (HICSS). Hawai.

Guttentag, D. A. (2010, October). Virtual Reality: Applications and Implications For Tourism. Tourism Management, 31, 637-651. doi:10.1016/j.tourman.2009.07.003

Hanoatabun, S. (2020). Dampak Covid-19 Terhadap Perekonomian Indonesia. Journal of Education, Psychology and Counseling, 2, 146-153. Retrieved Agustus 6, 2020

Huang, Y.-C., Backman, S. J., Backman, K. F., \& Moore, D. (2013). Exploring User Acceptance of 3D Virtual Worlds in Travel and Tourism Marketing. Tourism Management, 36, 490-501. doi:doi.org/10.1016/j.tourman.2012.09.009

Hyun, M. Y., \& O'Keefeb, R. M. (2012, January). Virtual Destination Image: Testing a Telepresence Model. Journal of Business Research, 65(1), 29-35. doi:doi.org/10.1016/j.jbusres.2011.07.011

Japutra, A., \& Situmorang, R. (2021). The repercussions and challenges of COVID-19 in the hotel industry: Potential strategies from a case study of Indonesia. International Journal of Hospitality Management, 95, 1-12. doi:https://doi.org/10.1016/j.ijhm.2021.102890

Javaid, M., Haleem, A., Vaishya, R., Bahl, S., Suman, R., \& Vaishe, A. (2020). Industry 4.0 technologies and their applications in fighting COVID-19 pandemic. Diabetes Metab Syndr., 14(4), 419-422. doi:https://10.1016/j.dsx.2020.04.032 
Jung, T., Tom Dieck, M., Moorhouse, N., \& Tom Dieck, D. (2017). Tourists' Experience of Virtual Reality Applications. IEEE conference on Consumer Electronics, Las Vegas. doi:10.1109/ICCE.2017.7889287

Kemenparekraf. (2021, Maret 17). Virtual Tour, Alternatif Berwisata di Tengah Pandemi COVID-19. Retrieved from Kemenparekraf/Baparekraf RI: https://www.kemenparekraf.go.id/ragam-pariwisata/Virtual-Tour\%2C-AlternatifBerwisata-di-Tengah-Pandemi-COVID_19

Kemp, S. (2021). Digital 2021: Indonesia. We are social and Hootsuite. Data Reportal. Retrieved Oktober 13, 2020, from https://datareportal.com/reports/digital-2020indonesia

Kim, M. J., Lee, C. K., \& Jung, T. (2018, December 26). Exploring Consumer Behavior in Virtual Reality Tourism Using an Extended Stimulus-Organism-Response Model. Journal of Travel Research, 1-21. doi:https://doi.org/10.1177/0047287518818915

Korže, S. Z. (2019, September 3). From Industry 4.0 to Tourism 4.0. Innovative Issues and Approaches in Social Sciences, 12(3), 29-52.

Lee, M.-C. (2010). Explaining and Predicting Users' Continuance Intention Toward e-learning: An Extension of The Expectation-Confirmation Model. Computers \& Education, 54, 506-516. Retrieved August 7, 2020

Localise SDG's. (2020, Oktober 21). Virtual Tour, Adaptasi Baru Sektor Pariwisata di Daerah pada Masa Pandemi COVID-19. Retrieved from localisesdgs-indonesia.org: https://localisesdgs-indonesia.org/beranda/v/virtual-tour-adaptasi-baru-sektorpariwisata-di-daerah-pada-masa-pandemi-covid-19

Mahardika, M. D. (2021, Februari 3). Digitalisasi, Good Governance, dan Pembangunan Berkelanjutan: Resep Sektor UMKM untuk Pemulihan Pasca-COVID-19. Retrieved from localisesdgs-indonesia.org: https://localisesdgsindonesia.org/beranda/v/digitalisasi-good-governance-dan-pembangunanberkelanjutan-resep-sektor-umkm-untuk-pemulihan-pasca-covid-19

Maranti, E. (2020, Juli 23). Potensi Virtual Tourism Bantu Industri Pariwisata. Retrieved from Marketeers: https://www.marketeers.com/potensi-virtual-tourism-bantu-industripariwisata/

Media Partners Asia (MPA). (2021). AMPD Online Video Consumer Insights \& Analytics 2021. Media Partners Asia.

Najafipour, A. A., Heidari, M., \& Faroonzanfar, M. H. (2014). Describing the Virtual Reality and Virtual Tourist Community : Applications and Implications for Tourism Industry. Kuwait Chapter of Arabian Journal of Business and Management Review, 3(12a), 1223. doi:10.12816/0018842

Pramudita, A. B. (2019, Desember 3). Implementasi VR di Indonesia Rendah. Retrieved from Warta Ekonomi: https://www.wartaekonomi.co.id/read259662/duh-implementasi-vrdi-indonesia-rendah-penyebabnya

Puspita, S. (2019, Marech 1). Tourism 4.0 Jadi Tren Pengembangan Pariwisata Dunia. (W. A. Prodjo, Editor) Retrieved August 7, 2020, from Kompas: https://travel.kompas.com/read/2019/03/01/070000127/tourism-4.0-jadi-trenpengembangan-pariwisata-dunia 
Putra, I. I. (2020, Maret 23). Portal Statistik Sektoral Provinsi DKI Jakarta. Retrieved from Statistik Ketenagakerjaan DKI Jakarta 2019: https://statistik.jakarta.go.id/statistikketenagakerjaan-dki-jakarta-2019/

Samuely, A. (2016). Hilton checks in virtual reality push via 360-degree video experience. Retrieved January 4, 2021, from Marketing Dive: https://www.marketingdive.com/ex/mobilemarketer/cms/news/video/22759.html

Sigala, M. (2020, June 2020). Tourism and COVID-19: Impacts and Implications for Advancing and Resetting Industry and Research. Journal of Business Research. doi:https://doi.org/10.1016/j.jbusres.2020.06.015

Silalahi, A. (2021). Perubahan Pola Hidup Pada Situasi COVID-19 Adaptasi Pada Pola Hidup Normal Baru. Conference: Disampaikan pada Acara Diskusi Ikatan Alumni Jurusan Kimia Unimed, 29 Mei 2020, oleh Prof. Dr. Albinus Silalahi, MS (Guru Besar Biokimia Unimed). Medan. doi:https//:10.13140/RG.2.2.10961.76646

Šimková, E., \& Holzner, J. (2014). Motivation of Tourism Participants. Procedia - Social and Behavioral Sciences, 660-664. doi:https//:10.1016/j.sbspro.2014.12.455

Singh, N., \& Lee, M. J. (2008). Exploring Perceptions Toward Education in 3-D Virtual Environments: An Introduction to "Second Life". Journal of Teaching in Travel \& Tourism, 8(4). doi:10.1080/15313220903047896

Stainton, H. (2020, April 17). Virtual tourism explained: What, why and where. Retrieved August 7, 2020, from Tourism Teacher: https://tourismteacher.com/virtual-tourism/\#0what-is-virtual-tourism

Surendran, P. (2012). Technology Acceptance Model: A Survey of Literature. International Journal of Business and Social Research, 2, 175-178. Retrieved August 7, 2020

Suryanto. (2021, Februari 3). Wisata virtual, tantangan baru turisme Indonesia. Retrieved from Antara News: https://www.antaranews.com/berita/1980246/wisata-virtualtantangan-baru-turisme-indonesia

The Jakarta Post. (2020, Mei 29). Seven virtual tour platforms to visit during the pandemic. Retrieved from The Jakarta https://www.thejakartapost.com/travel/2020/05/29/seven-virtual-tour-platforms-tovisit-during-the-pandemic.html

Wagler, A., \& Hanus, M. D. (2018). Comparing Virtual Reality Tourism to Real-Life Experience: Effects of Presence and Engagement on Attitude and Enjoyment. Communication Research Reports, O0(00), 1-9. doi:10.1080/08824096.2018.1525350

World Health Organisation. (2020, Agustus 6). Pneumonia of unknown cause - China. Retrieved from World Health Organisation: https://www.who.int/csr/don/05-january2020-pneumonia-of-unkown-cause-china/en/

Yuan, L., Hong, L., Chris, C., \& Rukai, C. (2016). An Exploration of Digital Tourism Design Based on Virtual Reality. ISSN: 1473-804x online, 1473-8031 print . doi:10.5013/IJSSST.a.17.02.15

Yuce, A., Arasli, H., Ozturen, A., \& Daskin, M. (2020). Sustainability, 12(16), 1-17. doi:https://doi.org/10.3390/su12166632

Yuliana, A., \& Lisdianto, E. (2017). Aplikasi Virtual Tour sebagai Media Promosi Objek Wisata di Stone Garden Kabupaten Bandung Barat. KOPERTIP: Jurnal Ilmiah Manajemen Informatika dan Komputer, 19-24. 